\title{
Utilization of pomegranate and guava seeds in the manufacture of corn chips (Doritos) enriched with soybeans
} Asteer V. Abd-EInoor, Marwa Z. Mahfouz

Home Economics Department, Nutrition \& Food Science, Faculty of Specific Education, Alexandria University

\section{INTRODUCTION}

Fruit seeds are sometimes considered as wastes, which are disposed of during processing or after human consumption. Researchers have sought to assess the nutritional values of many different fruit seeds, as they are rich in nutrients and can be used for medicinal purposes. In addition, their use reduces the problem of wastes disposal in industries (Raihana $\boldsymbol{e t}$ al., 2015).There is a great interest in the residues of vegetables and fruits such as seeds and husks produced during the manufacture of juice and jam, as it contains many important nutrients for human health such as antioxidants (polyphenols, pigments and tocopherol) and omega fatty acids (Hea et al., 2014). Due to the large amount of pomegranate and guava seeds residues, it has been used in the food industry as animal feed or in commercial cosmetics (Chaudhary and Tripathi, 2014).

Psidium guava (common name for guava) is a well-known to have seeds inside. The size of the seeds is very small and can be easily chewed. They are arranged in regular patterns. Their numbers range from 112 to 535 (Kumar $\boldsymbol{e t}$ al., 2011).Guava seeds make up about $6-12 \%$ of the weight of the entire fruit (Nicanor et al., 2000). Being round in shape and pale yellow structure, seeds were reported to contain about $16 \%$ oil, $7.6 \%$ protein, and $61.4 \%$ crude fibers (Prasad and Azeemoddin, 1994). Because of this fact, guava seeds have the potential to become a source of oil that can be used in food products and as a complement to food health (Zaini et al., 2011).

It is known that most parts of the pomegranate fruit have a great antioxidants activity (Adhami and Mukhtar, 2006). Pomegranate seeds, a byproduct of pomegranate juice, contain a range of nutritional ingredients such as sterol, tocopherol, punicic acid, and benzoic hydroxyl acids (Liu et al., 2009).

Corn is one of the most important foods in the world. It is a nutrient rich in many bioactive compounds and has a major role in human health. Consumption of corn and other whole grain products was found to decrease the risk of chronic diseases such as type 2 diabetes (Montonen et al., 2003), obesity (Melanson et al., 2006), cardiovascular disease (Mellen et al., 2008), some cancers (Mourouti et al., 2016), and the improvement of digestive tract health (Muir et al., 2004). 
Soybean, Glycine $\max ($ L.) Merrill, is a good source of protein (35-42\%), fat (16-27\%) and other bioactive compounds, this makes soybean one of the most valuable and common crops (Kumar et al., 2006). As a result, soybean meal is a valuable and desirable product for human nutrition, because it contains all the essential amino acids at a low cost compared to other highquality protein sources. Therefore, the study of the formation of amino acid from soybean is important for nutritional purposes and consumer acceptance of soybean food products, as they contribute to the taste of food (Gao et al., 2011).

Extruded snacks with high calories, fats and low protein content are unhealthy food to most consumers. Today, various techniques have been proposed to improve the quality of snacks. The use of waste's fruit processing products in extruded snacks is one of the most important techniques proposed (Kakaei et al., 2019). The addition of waste's fruit processing products to extruded snacks improves nutritional values due to the high content of dietary fiber, biologically active compounds and minerals for these by-products (Yagcl and Gogus, 2008).

The aim of this study was to prepare high quality healthy corn chips (Doritos) with high nutritional value from some fruit wastes (seeds of guava and pomegranate) and using legumes (soybean).

\section{MATERIALS AND METHODS Materials}

Pomegranate, guava, corn and soybean were obtained from Alexandria local market. The fruits were medium in size, and other ingredients including sun flower oil, food salt, spices such as cumin, turmeric were also purchased from Alexandria local market, Egypt.

The pomegranate and guava seeds remained after pulping were removed, washed several times with tap water. The seeds were dried in an ordinary dryer at $50^{\circ} \mathrm{C}$ for $12 \mathrm{hrs}$. The dried seeds were ground with a food processor (Kinwood) and stored in glass jars at $-18^{\circ} \mathrm{C}$ until analysis. Corn and soybean flour was prepared according to Isaac and Koleosho (2012).

\section{Preparation of corn chips (Doritos)}

To prepare Doritos chips, the dried ingredients were mixed as shown in Table (1) according to Riaz (2016), then the sun flower oil and warm water were gradually added until a smooth dough formed. The dough was spread with a very thin thickness, cut it in to triangles, then baked in a hot oven at $180^{\circ} \mathrm{C}$ until it was roasted and then served. All blends were prepared in different proportions in the same method. 
Table (1): Ingredients for different blends of Doritos chips

\begin{tabular}{|c|c|c|c|c|c|}
\hline Ingredients & $\begin{array}{c}\text { Control } \\
\text { corn } 100 \%\end{array}$ & $\begin{array}{l}\text { Corn+ GS } \\
(97+3 \%) \\
\end{array}$ & $\begin{array}{c}\text { Corn+PSR } \\
(97+3 \%) \\
\end{array}$ & $\begin{array}{c}\text { Corn+S+GS } \\
(87 \%+10 \%+3 \%) \\
\end{array}$ & $\begin{array}{c}\text { Corn+ S+PSR } \\
(87 \%+10 \%+3 \%) \\
\end{array}$ \\
\hline $\begin{array}{l}\text { Corn flour } \\
\text { (g) }\end{array}$ & 100 & 97 & 97 & 87 & 87 \\
\hline $\begin{array}{l}\text { Soybean } \\
\text { flour }(g)\end{array}$ & 0 & 0 & 0 & 10 & 10 \\
\hline GS flour (g) & 0 & 3 & 0 & 3 & 0 \\
\hline PSR flour (g) & 0 & 0 & 3 & 0 & 3 \\
\hline Food salt (g) & 1 & 1 & 1 & 1 & 1 \\
\hline Cumin (g) & 1 & 1 & 1 & 1 & 1 \\
\hline Tumeric (g) & 3 & 3 & 3 & 3 & 3 \\
\hline $\begin{array}{l}\text { Sunflower oil } \\
\text { (ml.) }\end{array}$ & 10 & 10 & 10 & 10 & 10 \\
\hline Water (ml.) & $\begin{array}{l}\text { added as } \\
\text { needed }\end{array}$ & $\begin{array}{l}\text { added as } \\
\text { needed }\end{array}$ & $\begin{array}{l}\text { added as } \\
\text { needed }\end{array}$ & added as needed & added as needed \\
\hline
\end{tabular}

GS: guava seeds, PSR: pomegranate seeds, S: soy bean

\section{Sensory evaluation}

The sensory characteristics were evaluated according to (Hooda and Jood, 2005).

\section{Chemical composition}

Proximate analysis of PSR, GS, soybean, corn and corn blends including crude fat, crude protein $(\mathrm{N} \times 6.25)$, crude fiber and ash were carried out according to the AOAC (2007).Fat content was extracted by the soxhlet technique AACC (1995). Crude protein determination was performed by the Kjeldahl technique AOAC (2007). The $\mathrm{N}$-free extract content was obtained by subtracting the percent total of the fat, protein, fiber and ash contents from $100 \%$.Caloric values were calculated from the sum of the percentages of crude protein and $\mathrm{N}$-free extract multiplied by a factor of 4 (kcal.g-1) plus the crude fat content multiplied by a factor of 9 (kcal.g-1) according to Zambrano et al. (2004).

The following mineral elements: $\mathrm{Ca}, \mathrm{Mg}, \mathrm{Zn}$, and Fe were measured in ash solution using Perkin Elmer atomic absorption spectrophotometer (Model 2380) as outlined in the AOAC (2007).whereas $\mathrm{Na}$ was determined using Flame Photometer Model PEP7 as described by the AOAC (2000). Total phosphorus was assayed calorimetrically at $630 \mathrm{~nm}$ using Carlzeiss Spekol colorimeter (AOAC, 1990).

\section{Fatty acids composition}

Preparation of fatty acids methyl esters of oils derived from PSR and GS was conducted by using $1 \%$ sulphuric acid in absolute methanol according to the Radwan (1978) technique. 


\section{Total amino acids composition}

Amino acids have been determined by a Beckman model $119 \mathrm{Cl}$ amino aci $\mathrm{d}$ analyzer (USA) using the method described by Spackman et al. (1958). Ninhydrin was used as a detective compound.

\section{Bioactive compounds and antioxidant activity}

A Jasso V-530 UV-Vis spectrophotometer was used to evaluate the total polyphenols for samples using the Folin-Ciocalteu reagent at $765 \mathrm{~nm}$. The total content of polyphenol was standardized against gallic acid and expressed as (mg of GAE/100 $\mathrm{g}$ sample) depending on the method of (Meyers $\boldsymbol{e t}$ al., 2003). According to Choi et al. (2002), total carotenoids were determined while flavonoids were determined using the method described by Gitelson et al. (2001). Isoflavones concentrations were calculated as $\mathrm{mg}$ of isoflavones per $100 \mathrm{~g}$ of soybean according to Tsangalis et al. (2002). DPPH assay described by Fernandez-Pachon et al. (2004) was used for measuring antioxidant activity.

\section{Antinutritional factors}

Trypsin inhibitor was extracted according to the method of Lin and Chen (1989).Trypsin inhibitor activity was set as the number of trypsin unit inhibited (TUI). Phytic acid was determined according to the method described by Wheeler and Ferrel (1971).

\section{In vitro protein digestibility}

According to the method described by Prakash and Prakash(1999), the digestibility of samples using the proteolytic enzymes pepsin followed by pancreatin was determined. The digestibility in relation to the sample s analyzed protein content was calculated as a percentage of the digested protein.

\section{Statistical analysis}

Using IBM SPSS software package version 20.0, data were fed to the co mputer and analyzed (Armonk, NY: IBM Corp) as outlined by Kirkpatrick and Feeney (2013). The Kolmogorov- Smirnov test was used to check the normality of variables distribution; Student t-test was used to compare two groups for normally distributed quantitative variables while ANOVA was used to compare more than two groups followed by Least significant difference (LSD) comparison. The relevance of the results obtained were evaluated at the rate of 0.05 (Kotz et al. 2006).

\section{RESULTS AND DISCUSSION Sensory evaluation for different blends of corn chips (Doritos)}

The sensory scores of corn chips (Doritos) evaluated by 30 persons are shown in Table (2). Five blends were used where the corn, pomegranate seeds, 
guava seeds, and soybeans were mixed together at $(97+3 \%)$ and $(87 / 10 / 3 \%)$. These ratios were the best accepted after testing many other concentrations during the pilot study performed before starting the research. The sensory evaluation of Doritos incorporated with various levels of corn, pomegranate seeds, guava seeds and soybean is presented in Table (2).

It can be observed that the taste when using Doritos with (corn 100\%), Corn + PSR $(97+3 \%)$ and Corn/S/PSR $(87 / 10 / 3 \%)$ was significantly higher than the values of Doritos with Corn + GS $(97+3 \%)$ and Corn/S/GS $(87 / 10 / 3 \%)$ at $8.93,8.79,8.73$ vs. 7.60 and 7.28 , respectively. On the other hand, no significant $(P \leq 0.05)$ differences were observed in odor for all Doritos blends. These results revealed that, the highest mean of color was shown in the control Doritos and corn + PSR $(97+3 \%)$, while the lowest was in corn/S/GS $(87 / 10 / 3 \%)$ and corn+GS $(97+3 \%)$ samples.

Overall acceptance score of corn chips (Doritos) formulations at corn/S/PSR (87/10/3) ratio had the highest hedonic score (8.36) compared with the other ratios for each $(97 \%$ corn $+3 \%$ GS), $(87 \%$ corn $+10 \%$ Soybean $+3 \%$ GS) and (97\% corn $+3 \%$ PSR) which scored significantly $(P \leq 0.05)$ less ratio (8.10, 7.42 and 5.58 , respectively). Whereas the highest score of overall acceptance for Doritos with $100 \%$ corn (8.67).

The data showed that there were a significant differences $(P \leq 0.05)$ between the corn chips prepared in taste, color, consistency, and overall acceptability. Generally, all formulated samples were significantly $(P \leq 0.05)$ accepted for all the sensory properties. The best blend was that contained only corn followed by corn/soybean/pomegranate seeds (87/10/3\%), while corn/pomegranate seeds $(97+3 \%)$ was less acceptable comparing with the other blends. In a similar study, Abd-El Haleem (2016) prepared biscuits enriched with guava seeds and pomegranate seeds and the general acceptance of these products was good.

\section{Table (2): Sensory evaluation for different blends of corn chips (Doritos)}

\begin{tabular}{cccccc}
\hline Samples & Taste & Color & consistency & Odor & $\begin{array}{c}\text { Overall } \\
\text { acceptability }\end{array}$ \\
\hline Control (corn 100\%) & $8.93 \pm 0.14^{\mathrm{a}}$ & $8.90 \pm 0.85^{\mathrm{a}}$ & $8.70 \pm 0.07^{\mathrm{a}}$ & $8.82 \pm 0.90^{\mathrm{a}}$ & $8.67 \pm 0.44^{\mathrm{a}}$ \\
Corn + PSR (97 + 3\%) $^{\mathrm{a}}$ & $8.79 \pm 0.55^{\mathrm{a}}$ & $8.71 \pm 0.71^{\mathrm{a}}$ & $8.20 \pm 0.71^{\mathrm{ab}}$ & $8.43 \pm 0.55^{\mathrm{a}}$ & $5.58 \pm 0.02^{\mathrm{c}}$ \\
Corn + GS (97 +3\%) $^{\mathrm{9}}+7.60 \pm 0.17^{\mathrm{b}}$ & $8.12 \pm 0.78^{\mathrm{ab}}$ & $7.80 \pm 0.40^{\mathrm{bc}}$ & $8.63 \pm 0.01^{\mathrm{a}}$ & $8.10 \pm 0.16^{\mathrm{ab}}$ \\
Corn / S/PSR 87/10/3 $^{\mathrm{a}}$ & $8.73 \pm 0.21^{\mathrm{a}}$ & $8.56 \pm 0.82^{\mathrm{a}}$ & $7.37 \pm 0.68^{\mathrm{bc}}$ & $8.26 \pm 0.58^{\mathrm{a}}$ & $8.36 \pm 0.29^{\mathrm{a}}$ \\
Corn /S/GS 87/10/3 & $7.28 \pm 0.10^{\mathrm{b}}$ & $7.18 \pm 0.21^{\mathrm{b}}$ & $7.21 \pm 0.25^{\mathrm{c}}$ & $7.89 \pm 0.88^{\mathrm{a}}$ & $7.42 \pm 0.88^{\mathrm{b}}$ \\
\hline
\end{tabular}

* (PSR) Pomegranate seeds residues, (GS) guava seeds and (S) soybean. Data was expressed using Mean \pm SD.

Means in the same column with common letters are not significant (i.e. Means with Different letters are significant) 


\section{Proximate analysis for PSR, GS, corn, soybean and different blends of corn chips (Doritos)}

The proximate analysis and minerals of pomegranate seeds residues (PSR), guava seeds (GS), corn and soybean are tabulated in Table (3-a \&3$\mathrm{b} \& 3-\mathrm{c})$. Data of proximate composition indicated that GS contained a significant $(P \leq 0.05)$ lower amount of crude protein, crude fat and ash contents $(10.38,16.94$ and $1.71 \%$, respectively) compared with those of PSR (12.59, 21.39 and $3.17 \%$, respectively). While, GS contained a significant $(P \leq 0.05)$ higher amount of moisture, crude fiber and $\mathrm{N}$-free extract contents $(2.49,66.85$ and $4.12 \%$,respectively) compared with PSR (0.90, 59.9 and 2.95 $\%$,respectively). The moisture value found in this study for GS are lower than those found by Fontanari et al. (2008), who obtained a moisture value of $8.3 \mathrm{~g} / 100 \mathrm{~g}$ for guava seed powder. The ash value found was $1.71 \%$, This value is less than the results of other authors, such as Martínez et al. (2012), who obtained an ash content of $2.4 \%$ for guava.

Table (3-a): Proximate analysis of PSR, GS, corn, soybean

\begin{tabular}{|c|c|c|c|c|c|c|c|c|}
\hline & Components & $\begin{array}{c}\text { Moisture } \\
\%\end{array}$ & $\begin{array}{c}\text { Crude } \\
\text { protein\% }\end{array}$ & $\begin{array}{l}\text { Crude } \\
\text { fat } \%\end{array}$ & $\begin{array}{c}\text { Crude } \\
\text { Fiber\% }\end{array}$ & Ash\% & $\begin{array}{c}\mathrm{N} \text {-free } \\
\text { extract\% }\end{array}$ & $\begin{array}{c}\text { Calories } \\
\text { kcal/100g }\end{array}$ \\
\hline \multirow{4}{*}{$\begin{array}{c}\text { Raw } \\
\text { materials }\end{array}$} & *PSR & $0.90 \pm 0.16^{b}$ & $12.59 \pm 0.64^{\mathrm{a}}$ & $21.39 \pm 0.42^{\mathrm{a}}$ & $59.9 \pm 0.24^{b}$ & $3.17 \pm 0.1^{\mathrm{a}}$ & $2.95 \pm 0.11^{b}$ & $254.67 \pm 0.30^{a}$ \\
\hline & GS & $2.49 \pm .42^{\mathrm{a}}$ & $10.38 \pm 0.77^{b}$ & $16.94 \pm 0.23^{b}$ & $66.85 \pm 0.44^{\mathrm{a}}$ & $1.71 \pm 0.45^{b}$ & $4.12 \pm 0.20^{\mathrm{a}}$ & $210.46 \pm 0.77^{b}$ \\
\hline & $* *$ Corn & $8.19 \pm 0.15^{\mathrm{a}}$ & $11.99 \pm 0.8^{\mathrm{b}}$ & $13.01 \pm 0.34^{\mathrm{a}}$ & $2.19 \pm 0.62^{b}$ & $2.29 \pm 0.88^{\mathrm{b}}$ & $70.52 \pm 0.13^{a}$ & $447.13 \pm 0.63^{\mathrm{a}}$ \\
\hline & Soybean & $5.28 \pm 0.08^{b}$ & $30.1 \pm 0.81^{\mathrm{a}}$ & $4.11 \pm 0.88^{b}$ & $9.30 \pm 0.52^{\mathrm{a}}$ & $6.23 \pm 0.23^{\mathrm{a}}$ & $50.26 \pm 0.11^{\mathrm{b}}$ & $358.43 \pm 0.60^{b}$ \\
\hline
\end{tabular}

Data was expressed using Mean \pm SD. (PSR) Pomegranate seeds residues, (GS) guava seeds

* Means in the same column in PSR and GS are not significant (i.e. Means with Different letters are significant)

**Means in the same column in Corn and Soybean are not significant (i.e. Means with Different letters are significant).

Observing the results of lipid analysis for GS shown in Table 3-a, the results presented in this study are more than to those reported by Silva $\boldsymbol{e t}$ al. (2009) who found that crude fat was $11.71 \%$ for the guava seed on a dry basis. Rowayshed et al. (2013) determined the chemical composition of PSR and found that moisture, crude protein, crude fat, ash, crude fibers and $\mathrm{N}$-free extract contents were $5.82,13.66,29.60,1.49,39.36$ and $13.12 \%$ on dry weight basis, respectively. The difference in content may vary depending on the soil and agriculture environment. The relatively high protein contents in each sample showed that samples could be considered a good source of protein and they may contribute significantly to humans' daily protein requirements. 
Values of chemical composition showed that corn has a significant $(P \leq 0.05)$ increase in moisture, fats, $\mathrm{N}$-free extract and calories $(8.19,13.01$, 70.52 and $447.13 \%$, respectively) compared to the values of soybean (5.28, $4.11,50.26$ and $358.43 \%$, respectively), Whereas corn has a significant $(P \leq 0.05)$ reduction in protein, ash and crude fibers $(11.99,2.29$ and $2.19 \%$, respectively) compared to those of soybean (30.1, 6.23 and $9.30 \%$, respectively). Rashwan and Mohamady (2015) found that corn contains 10.5,4.7,1.6,1.4 and 81.8\% for protein, lipids, ash, fibers and carbohydrates, respectively. Also, Guria (2006) found the value of moisture, crude protein, crude fat, crude fiber and $\mathrm{N}$-free extract contents for corn were 8.03, 10.29, $5.53,1.34,73.58$,respectively.

The soybean's composition varies with the location, growing season and $\mathrm{v}$ ariety (Bakal et al., 2017). Nonetheless, Seo et al. (2012) found that the average for the main nutrients in soybean are $8.1 \%$ moisture, $18.1 \%$ lipid, 35.1 $\%$ proteins and $6.0 \%$ ash $(\mathrm{g} / 100 \mathrm{~g})$.

Drought and temperature also affect the chemical composition of soybeans. Many researchers found that there was a difference in moisture content between soybean samples and this may be due to conditions legumes drying after harvest, legumes ability to lose moisture and storage period (Coradi et al., 2016). In addition, high temperatures during soybean growth were found to be associated with lower fat content. However, this depends on other factors such as water stress, which affects the production of fat by affecting the growth and development of grains (Thuzar, 2010).

The data of the chemical composition of corn chips (Doritos) are explained in Tables (3-b). Chemical composition of Doritos showed that Doritos with $100 \%$ corn has a significant $(P \leq 0.05)$ lower ratio of moisture, crude protein, fat, crude fiber, and ash contents $(7.15,10.99,14.01,2.25$ and $2.59 \%$, respectively) compared to other blends. Whereas the Doritos enriched with 3\% PSR have a significant $(P \leq 0.05)$ higher ratio of crude protein, fat and calories compared to Doritos with $3 \%$ Gs. On the other hand the blends with $(87 \%$ corn $+10 \%$ Soybean $+3 \%$ PSR and $87 \%$ corn $+10 \%$ Soybean $+3 \%$ GS) have a significant $(P \leq 0.05)$ higher ratio of moisture, crude protein, crude fiber and ash content when compared with other blends. While N-free extract, in blends (97\% corn $+3 \%$ PSR and 97\% Corn $+3 \%$ GS) have a significant $(P \leq 0.05)$ higher ratio (65.02 and 66.22, respectively) compared to $\mathrm{N}$-free extract content of $87 \%$ corn $+10 \%$ Soybean $+3 \%$ PSR and $87 \%$ corn $+10 \%$ Soybean $+3 \%$ GS (62.11 and 63.28, respectively). 
Table (3-b): Proximate analysis of different blends of corn chips (Doritos)

\begin{tabular}{|c|c|c|c|c|c|c|c|c|}
\hline & Components & $\begin{array}{c}\text { Moisture } \\
\%\end{array}$ & $\begin{array}{c}\text { Crude } \\
\text { protein } \%\end{array}$ & Crude fat $\%$ & $\begin{array}{l}\text { Crude } \\
\text { Fiber\% }\end{array}$ & Ash\% & $\begin{array}{c}\text { N-free } \\
\text { extract } \%\end{array}$ & $\begin{array}{c}\text { Calories } \\
\text { kcal/100g }\end{array}$ \\
\hline \multirow{5}{*}{$\begin{array}{c}* * * \\
\text { Doritos } \\
\text { blends }\end{array}$} & $\begin{array}{c}\text { Control } \\
\text { (Corn100\%) }\end{array}$ & $7.15 \pm 0.87^{\mathrm{a}}$ & $10.99 \pm 0.03^{c}$ & $14.01 \pm 0.53^{\mathrm{c}}$ & $2.25 \pm 0.78^{b}$ & $2.59 \pm 0.76^{\mathrm{a}}$ & $70.16 \pm 0.61^{\mathrm{a}}$ & $450.69 \pm 0.02^{b}$ \\
\hline & $\begin{array}{c}\text { Corn+PSR } \\
(97+3 \%)\end{array}$ & $7.18 \pm 0.40^{\mathrm{a}}$ & $12.01 \pm 0.66^{\mathrm{b}}$ & $16.04 \pm 0.01^{\mathrm{a}}$ & $3.9 \pm 0.60^{a}$ & $3.02 \pm 0.87^{\mathrm{a}}$ & $65.02 \pm 0.42^{\mathrm{c}}$ & $452.48 \pm 0.78^{\mathrm{a}}$ \\
\hline & $\begin{array}{l}\text { Corn+GS } \\
(97+3 \%)\end{array}$ & $7.22 \pm 0.17^{\mathrm{a}}$ & $11.94 \pm 0.60^{\mathrm{b}}$ & $14.87 \pm 0.29^{\mathrm{b}}$ & $4.12 \pm 0.50^{\mathrm{a}}$ & $2.85 \pm 0.69^{\mathrm{a}}$ & $66.22 \pm 0.32^{\mathrm{b}}$ & $446.47 \pm 0.38^{\mathrm{c}}$ \\
\hline & $\begin{array}{c}\text { Corn/S/PSR } \\
(87 / 10 / 3)\end{array}$ & $7.73 \pm 0.19^{\mathrm{a}}$ & $13.82 \pm 0.73^{\mathrm{a}}$ & $15.24 \pm 0.44^{\mathrm{b}}$ & $4.98 \pm 0.13^{\mathrm{a}}$ & $3.85 \pm 0.07^{\mathrm{a}}$ & $62.11 \pm 0.30^{\mathrm{e}}$ & $440.88 \pm 0.68^{\mathrm{e}}$ \\
\hline & $\begin{array}{c}\text { Corn/S/GS } \\
(87 / 10 / 3)\end{array}$ & $7.95 \pm 0.17^{\mathrm{a}}$ & $13.75 \pm 0.08^{\mathrm{a}}$ & $14.98 \pm 0.15^{\mathrm{b}}$ & $4.53 \pm 0.80^{\mathrm{a}}$ & $3.46 \pm 0.42^{\mathrm{a}}$ & $63.28 \pm 0.15^{\mathrm{d}}$ & $445.28 \pm 0.45^{\mathrm{d}}$ \\
\hline
\end{tabular}

These data explained that blends enriched with soybean included high amount of protein, ash, crude fiber and moisture and low amount of $\mathrm{N}$-free extract. These results are different from Aly (2019) whereas he enriched biscuits with GS and the study showed that biscuits enriched with 5\% GS has $17.2 \%$ fats, $1.4 \%$ ash and $69.8 \%$ $\mathrm{N}$-free extract whereas the data is so close for protein $(11.6 \%)$.

Minerals content of PSR and GS are presented in Table (3-c). Results showed that PSR contained a significant $(P \leq 0.05)$ increase of $\mathrm{Ca}, \mathrm{Na}, \mathrm{Mg}, \mathrm{Fe}$ and $\mathrm{Ph}(465.3,352.6,232.4,3.45$ and $990.09 \mathrm{mg} / 100 \mathrm{~g}$, respectively) compared with the same minerals of GS $(257.3,162.0,190.0,1.18$ and $752.13 \mathrm{mg} / 100 \mathrm{~g}$, respectively). While the content of zinc in PSR $(11.6 \mathrm{mg} / 100 \mathrm{~g})$ less than GS (20.99 mg/100g,respectively). PSR values differ from the result of Rowayshed et al. (2013) who found that the content of $\mathrm{Na}, \mathrm{Fe}, \mathrm{Zn}, \mathrm{Mn}, \mathrm{Cu}$ and $\mathrm{Se}$ in PSR were $33.03,10.88,5.54,2.26,3.82$ and $0.23 \mathrm{mg} / 100 \mathrm{~g}$ on dry matter, respectively. The results confirmed that PSR and GS are a good source of macro and micro elements so it should be used in food fortification and enrichment. The content of these seeds of sodium is considered low according to the World Health Organization (2013), which recommends taking less than $1.7 \mathrm{~g} /$ day (1700 mg / day) of this mineral. Uchôa et al. (2008) assessed magnesium in guava seeds and found that it contained $0.19 \mathrm{mg} / 100 \mathrm{~g}$. Gondim et al. (2005) found that biological reactions are highly dependent on magnesium and sulfur. When compared the iron content of pomegranate seeds, it was found to represent $24.64 \%$ of the adult dietary intake (DRI), which is 14 $\mathrm{mg} /$ day (Brasil, 2005). In estimating the amount of zinc contained in pomegranate and guava seeds in this study, the values found were $(11.61 \pm 0.63$ and $20.99 \pm 0.35 \mathrm{mg} / 100 \mathrm{~g}$, respectively). When comparing these values with the recommended adult amounts of $15 \mathrm{mg} /$ day, they were found to represent 77.4 and $139.9 \%$ of the recommended amount. 
Analysis of minerals for corn and soybean in (Table 3-c) showed that soybean has a significant $(P \leq 0.05)$ increase in $\mathrm{Fe}, \mathrm{Ca}, \mathrm{Zn}, \mathrm{Mg}$ and phosphorus $(14.6,298.32,2.1,244.42$ and 643.15, respectively) compare with those of corn $(1.36,0.72,0.21,39.02$ and 30.0 , respectively) while the soybean showed significantly $(P \leq 0.05)$ decrease in sodium $(2.98 \mathrm{mg} / 100 \mathrm{~g})$ compared to corn (198.0 mg/100g). Rashwan and Mohamady (2015) determined the minerals content of corn and found the values as follow 360, 120, 128 and 3.60 (mg/100g on dry weight basis) For $\mathrm{Ca}, \mathrm{P}, \mathrm{Mg}$ and $\mathrm{Fe}$, respectively. Also, Guria (2006) found the content of iron, copper, manganese and zinc were 1.92, 0.33, $0.18,1.65 \mathrm{mg}$, respectively.

Table (3-c): Minerals content of PSR, GS, corn, soybean and different blends of corn chips (Doritos)

\begin{tabular}{|c|c|c|c|c|c|c|c|}
\hline \multirow{6}{*}{$\begin{array}{c}\text { Raw } \\
\text { materials }\end{array}$} & \multirow{6}{*}{$\begin{array}{l}\text { Components } \\
* \text { PSR } \\
\text { GS } \\
* * \text { Corn } \\
\text { Soybean } \\
\end{array}$} & \multicolumn{6}{|c|}{ Minerals (mg/100g DM) } \\
\hline & & Calcium & Sodium & Magnesium & Iron & Zinc & Phosphorus \\
\hline & & $465.3 \pm 0.18^{\mathrm{a}}$ & $352.6 \pm 0.24^{\mathrm{a}}$ & $232.4 \pm 0.33^{\mathrm{a}}$ & $3.45 \pm 0.71^{\mathrm{a}}$ & $11.61 \pm 0.63^{b}$ & $990.09 \pm 0.58^{\mathrm{a}}$ \\
\hline & & $257.3 \pm 0.30^{\mathrm{b}}$ & $162.0 \pm 0.71^{\mathrm{b}}$ & $190.0 \pm 0.67^{b}$ & $1.18 \pm 0.09^{\mathrm{b}}$ & $20.99 \pm 0.35^{\mathrm{a}}$ & $752.13 \pm 0.41^{\mathrm{b}}$ \\
\hline & & $0.72 \pm 0.71^{\mathrm{b}}$ & $198.0 \pm 0.32^{\mathrm{a}}$ & $39.02 \pm 0.07^{b}$ & $1.36 \pm 0.02^{\mathrm{b}}$ & $0.21 \pm 0.88^{\mathrm{b}}$ & $30.0 \pm 0.17^{\mathrm{b}}$ \\
\hline & & $298.32 \pm 0.3^{\mathrm{a}}$ & $2.98 \pm 0.01^{\mathrm{b}}$ & $244.42 \pm 0.4^{\mathrm{a}}$ & $14.6 \pm 0.2^{\mathrm{a}}$ & $2.1 \pm 0.10^{\mathrm{a}}$ & $643.15 \pm 0.05^{\mathrm{a}}$ \\
\hline \multirow{5}{*}{$\begin{array}{c}\text { ***Doritos } \\
\text { blends }\end{array}$} & $\begin{array}{l}\text { Control } \\
\text { (Corn100\%) }\end{array}$ & $0.78 \pm 0.54^{\mathrm{e}}$ & $202.0 \pm 0.24^{b}$ & $41.52 \pm 0.69^{\mathrm{e}}$ & $1.37 \pm 0.72^{b}$ & $\pm 0.01^{\mathrm{b}}$ & $32.01 \pm 0.35^{\mathrm{e}}$ \\
\hline & $\begin{array}{l}\text { Corn+PSR } \\
(97+3 \%)\end{array}$ & $14.64 \pm 0.65^{\mathrm{c}}$ & $207.63 \pm 0.57^{\mathrm{a}}$ & $44.81 \pm 0.13^{\mathrm{c}}$ & $1.43 \pm 0.37^{\mathrm{b}}$ & $0.50 \pm 0.31^{\mathrm{a}}$ & $59.80 \pm 0.36^{\mathrm{c}}$ \\
\hline & $\begin{array}{l}\text { Corn+GS } \\
(97+3 \%)\end{array}$ & $8.40 \pm 0.26^{\mathrm{d}}$ & $196.92 \pm 0.69^{\mathrm{c}}$ & $43.54 \pm 0.39^{d}$ & $1.37 \pm 0.87^{b}$ & $0.81 \pm 0.22^{\mathrm{a}}$ & $53.66 \pm 0.40^{\mathrm{d}}$ \\
\hline & $\begin{array}{l}\text { Corn/S/PSR } \\
(87 / 10 / 3)\end{array}$ & $44.40 \pm 0.55^{\mathrm{a}}$ & $183.13 \pm 0.45^{\mathrm{d}}$ & $65.35 \pm 0.05^{\mathrm{a}}$ & $2.78 \pm 0.02^{\mathrm{a}}$ & $0.70 \pm 0.18^{\mathrm{a}}$ & $122.11 \pm 0.68^{a}$ \\
\hline & $\begin{array}{l}\text { Corn/S/GS } \\
(87 / 10 / 3)\end{array}$ & $38.16 \pm 0.61^{b}$ & $177.42 \pm 0.24^{\mathrm{e}}$ & $64.08 \pm 0.59^{b}$ & $2.70 \pm 0.25^{\mathrm{a}}$ & $0.97 \pm 0.42^{\mathrm{a}}$ & $114.97 \pm 0.77^{\mathrm{b}}$ \\
\hline
\end{tabular}

Data was expressed using Mean \pm SD. (PSR) Pomegranate seeds residues, (GS) guava seeds.

* Means in the same column in PSR and GS are not significant (i.e. Means with Different letters are significant)

**Means in the same column in Corn and Soybean are not significant (i.e. Means with Different letters are significant)

***:Means in the same column in Doritos blends are not significant (i.e. Means with Different letters are significant)

Soybeans contain a significant amounts of iron and calcium (Miller, 2008). The bioavailability of certain minerals, such as zinc, may be adversely affected by phytic acid (Dahdouha $\boldsymbol{e t}$ al., 2019). Zhang $\boldsymbol{e t}$ al. (2010) found that there was a significant difference in the mineral content of the soybean due to different environment and genotype. From the previous discussion of the results, it can be concluded that guava, pomegranate seeds, corn and soybean are a good source of many nutrients.

Minerals content for corn chips blends (Doritos) are presented in Table (3-c). The results indicated that the use of a mixture of corn, guava seeds, pomegranate seeds and soybeans in various proportions increased the mineral content. Magnesium content increased slightly, but significantly, after preparation of Doritos with different blends, This is in agreement with Suri and Tanumihardjo (2016), which found that the magnesium content increases in the dough after preparation from 165 to $180 \mathrm{mg} / 100 \mathrm{~g}$. Increases in 
phosphorous and iron in all blends may be due to a decrease in the phytic acid content, as will be explained later. This result is consistent with (Hambidge $\boldsymbol{e} t$ al., 2005), which found that food preparation processes that reduce phytic acid lead to increased availability of phosphorous and iron. The low zinc content in the prepared Doritos from corn only may be caused by the maillard reaction that occurred during heat treatment, This result is consistent with Prasanthi $\boldsymbol{e t}$ al. (2017), who estimated the zinc content in corn flakes and corn grits, and found that the grits contained a higher percentage of zinc compared to the corn flakes that were exposed to this reaction, which made zinc less available. The results showed that this percentage increases in the other Doritos mixtures, depending on the ingredients used that contain zinc.

\section{Fatty acids composition for PSR and GS oils}

Fatty acid composition of oils extracted from PSR and GS are illustrated in Table (4). It is obvious that the fatty acid of GS include higher amount of capric, hendecanoic, palmitic, heptadecanoic, stearic and behenic $(0.69,0.32,5.31,0.08,6.42$ and $0.20 \%$, respectively) compared with fatty acid of PSR $(0.28,0.19,3.49,0.06$, 2.29 and $0.19 \%$, respectively). Whereas GS has insignificant $(P \leq 0.05)$ decrease in caproic,myrsitic, pentodecanoic and arachidic $(0.39,0.16,0.07$ and $0.16 \%$, respectively) compared to PSR $(0.79,0.18,0.36$ and $0.32 \%$, respectively).

\section{Table (4): Fatty acids composition for PSR and GS oils}

\begin{tabular}{lcc}
\hline Fatty acids (\%) & $*$ PSR & $* * \mathbf{G S}$ \\
\hline Caproic & $0.79 \pm 0.22^{\mathrm{a}}$ & $0.39 \pm 0.16^{\mathrm{a}}$ \\
Caprylic & $1.08 \pm 0.20$ & - \\
Capric & $0.28 \pm 0.65^{\mathrm{a}}$ & $0.69 \pm 0.26^{\mathrm{a}}$ \\
Hendecanoic & $0.19 \pm 0.14^{\mathrm{a}}$ & $0.32 \pm 0.81^{\mathrm{a}}$ \\
Lauric & $0.09 \pm 0.79^{\mathrm{a}}$ & $0.09 \pm 0.10^{\mathrm{a}}$ \\
Myrsitic & $0.18 \pm 0.42^{\mathrm{a}}$ & $0.16 \pm 0.85^{\mathrm{a}}$ \\
Pentodecanoic & $0.36 \pm 0.22^{\mathrm{a}}$ & $0.07 \pm 0.28^{\mathrm{a}}$ \\
Palmitic & $3.49 \pm 0.48^{\mathrm{b}}$ & $5.31 \pm 0.67^{\mathrm{a}}$ \\
Heptadecanoic & $0.06 \pm 0.34^{\mathrm{a}}$ & $0.08 \pm 0.24^{\mathrm{a}}$ \\
Stearic & $2.29 \pm 0.56^{\mathrm{b}}$ & $6.42 \pm 0.23^{\mathrm{a}}$ \\
Arachidic & $0.32 \pm 0.40^{\mathrm{a}}$ & $0.16 \pm 0.71^{\mathrm{a}}$ \\
Behenic & $0.19 \pm 0.43^{\mathrm{a}}$ & $0.20 \pm 0.49^{\mathrm{a}}$ \\
Total saturated fatty acids & $9.32 \pm 0.49^{\mathrm{b}}$ & $13.89 \pm 0.77^{\mathrm{a}}$ \\
Myristoleic & $0.61 \pm 0.60^{\mathrm{a}}$ & $0.35 \pm 0.37^{\mathrm{a}}$ \\
Margaroleic & $0.16 \pm 0.86^{\mathrm{a}}$ & $0.28 \pm 0.84^{\mathrm{a}}$ \\
Palmitoleic & $3.01 \pm 0.08^{\mathrm{a}}$ & $1.11 \pm 0.77^{\mathrm{b}}$ \\
Oleic & $9.36 \pm 0.14^{\mathrm{a}}$ & $6.10 \pm 0.61^{\mathrm{b}}$ \\
Linoleic & $13.85 \pm 0.36^{\mathrm{b}}$ & $72.32 \pm 0.32^{\mathrm{a}}$ \\
Linolenic & $60.48 \pm 0.47^{\mathrm{a}}$ & $7.02 \pm 0.05^{\mathrm{b}}$ \\
Eicosenic & $0.95 \pm 0.32^{\mathrm{a}}$ & $0.38 \pm 0.35^{\mathrm{a}}$ \\
Docosadienoic & $1.22 \pm 0.42^{\mathrm{a}}$ & $0.09 \pm 0.29^{\mathrm{b}}$ \\
Total unsaturated fatty acids & $89.64 \pm 0.09^{\mathrm{a}}$ & $87.65 \pm 0.24^{\mathrm{b}}$ \\
\hline
\end{tabular}

Data was expressed using Mean \pm SD. Values followed by the same letter in a row are not significantly (i.e. Means with Different letters are significant)

Pairwise comparison bet. each 2 groups was done using student t-test

different at $P \leq 0.05$.* (PSR) Pomegranate seeds residues and **(GS) guava seeds. 
Total saturated fatty acids for PSR and GS were 9.32 and $13.9 \%$, respectively. Also, the fatty acids pattern revealed that the total unsaturated content were $(89.64 \%)$ and $(87.65 \%)$ for PSR and GS oils, respectively. Linolenic acid was found to be the dominant unsaturated fatty acid $(60.48 \%)$ in PSR oil, while linoleic acid was the major one (72.32\%) in GS oil.

These results are consistent with Opute (2008) which found that linoleic acid is found in a very large proportion in guava seeds, accounting for about $51 \%$ of total fatty acids. Also, Uchôa-thomaz et al. (2014) found that guava seeds are rich in unsaturated fatty acids $(87.06 \%)$, especially oleic acid and linoleic acid. The presence of unsaturated fatty acids in foods has a significant role in lowering blood cholesterol levels and within the treatment of atherosclerosis (Ander et al., 2003).Wu and Tian (2017) analyzed the fatty acids in pomegranate seed oil, where it was found that punicic is the most abundant fatty acid with $60 \%$ of the fatty acids, followed by oleic acid, linoleic acid, and palmitic acid. The seeds of mature pomegranate fruits in the local Egyptian markets were studied by El-Nemr et al. (1990) where it was found that the total fat content was $27.2 \%$ and the percentage of saturated fatty acids was $83.6 \%$ of the total fatty acids. caprylic acid was the most present $(36.3 \%)$, followed by stearic acid, oleic and linoleic acids out of 11 estimated fatty acids, But no results were reported for punicic acid or linolenic acid.

\section{Total amino acids composition of PSR, GS, soybean, corn and different blends of corn chips (Doritos)}

The amino acids composition of PSR, GS, soybean, corn and different blends of corn chips (Doritos) are showed in Table (5-a, 5-b). It was obvious that PSR contains higher amounts of lysine, leucine and histadine $(2.08,7.59$ and 2.99, respectively) compared with GS amino acids (1.75, 7.19 and 2.82, respectively); the opposite was noticed for the other essential amino acids, since GS had a higher content of methionine, isoleucine, phenylalanine, cysteine, threonine, tyrosine and valine compared with amino acids of PSR. It could be noted that both PSR and GS exhibited much higher content of methionine, isoleucine, phenylalanine, tyrosine, valine and histidine, than the reference protein pattern of FAO/WHO (2002). The results of non-essential amino acids showed that PSR has a higher amount of glycine, aspartic, proline and glutamic (7.60, 6.40, 6.22 and 23.49 , respectively) compared to GS $(4.92,2.81,3.55$ and 16.72 , respectively). Whereas PSR has a low amount of alanine, arginine and serine $(5.48,6.69$ and 3.49 , respectively) compared with data of GS $(7.72,9.89$ and 5.55 , respectively).

Amino acids were studied in two varieties of pomegranate seeds found in Tunisia by Elfalleh $\boldsymbol{e t}$ al. (2011), also been studied in Egypt by Rowayshed $\boldsymbol{e t}$ al. (2013). Both recorded high levels of aspartate $(1.9$ and $1.21 \mathrm{~g} / 100 \mathrm{~g}$, arginine 1.9 and $1.47 \mathrm{~g} / 100 \mathrm{~g}$, respectively) and glutamate $(3.5 \mathrm{~g} / 100 \mathrm{~g})$, respectively) in dry seeds. 
Table (5-a): Amino acids composition of PSR, GS, soybean and corn

\begin{tabular}{|c|c|c|c|c|c|}
\hline Amino acid g/100 g protein & *PSR & $* * \mathbf{G S}$ & Soybean & Corn & $\begin{array}{c}\text { FAO } \\
\text { /WHO } \\
\text { Pattern } \\
(\mathbf{2 0 0 2}) \\
\end{array}$ \\
\hline \multicolumn{6}{|l|}{ Essential A.A. } \\
\hline Phenylalanine & 3.42 & 4.01 & 4.85 & 3.59 & 2.8 \\
\hline Histidin & 2.99 & 2.82 & 4.67 & 6.32 & 1.8 \\
\hline Isoleucin & 5.35 & 6.05 & 5.87 & 3.45 & 4.2 \\
\hline Leucine & 7.59 & 7.19 & 5.69 & 7.60 & 6.3 \\
\hline Lysine & 2.08 & 1.75 & 5.91 & 2.01 & 5.2 \\
\hline Methionine & 2.98 & 3.90 & 2.81 & 4.05 & 2.2 \\
\hline Threonine & 3.39 & 3.99 & 1.32 & 2.50 & 2.7 \\
\hline Valine & 4.88 & 6.39 & 5.89 & 5.12 & 4.2 \\
\hline Tryptophan & N.D & N.D & N.D & N.D & \\
\hline Total-essential A.A. & 32.68 & 36.10 & 37.01 & 34.64 & 29.4 \\
\hline \multicolumn{6}{|l|}{ Non-essential } \\
\hline Alanine & 5.48 & 7.72 & 6.40 & 4.42 & \\
\hline Aspartic acid & 6.40 & 2.81 & 8.32 & 7.08 & \\
\hline Cysteine & 0.51 & 0.69 & 2.05 & 4.21 & \\
\hline Glutamic acid & 23.49 & 16.72 & 8.40 & 7.65 & \\
\hline Glycine & 7.60 & 4.92 & 7.60 & 5.09 & \\
\hline Proline & 6.22 & 3.55 & 5.30 & 5.57 & \\
\hline Serine & 3.49 & 5.55 & 6.73 & 5.76 & \\
\hline Tyrosine & 3.68 & 3.96 & 5.20 & 4.86 & \\
\hline Arginine & 6.69 & 9.89 & 5.75 & 3.64 & \\
\hline Total non-essential a. a. & 63.56 & 55.81 & 55.75 & 48.28 & \\
\hline Total (TEAA + TNEAA) & 96.24 & 91.91 & 92.76 & 82.92 & \\
\hline Ar EAA (Phe + Tyr) & 7.10 & 7.97 & 10.05 & 8.45 & \\
\hline TSAA(Meth+Cys) & 3.49 & 4.59 & 4.86 & 8.26 & \\
\hline
\end{tabular}

*(PSR): Pomegranate seeds residues and **(GS) guava seeds.

N.D: Not Determined

These values depended on climate, genotype and growth conditions. They also found that the seeds content of amino acids was similar in composition to the peels in the sample estimated in Egypt. When comparing the essential amino acids content of pomegranate seeds to the requirements of FAO / WHO by Elfalleh $\boldsymbol{e t}$ al. (2011) they were found to be significantly higher than these requirements for adults. As a result of the lack of these essential amino acids in most foods, it is recommended to use these seeds as food supplements. El Anany (2015) pointed out that guava seeds have a large percentage of essential amino acids and account for $35.19 \%$ of the total amino acids content. The protein of guava seeds was rich in essential amino acids such as threonine, isoleucine, total aromatic amino acids, tryptophan and total sulfur amino acids compared with the FAO/WHO (1991) reference. Total amount of non-essential amino acids represented $64.81 \%$ of the total amino acids content. Glycine, 
arginine and glutamic acids were found to be the major non-essential amino acids in guava seeds protein $18.75,8.52$ and $9.06 \%$, respectively.

The values of amino acids for soybean and corn are showed in (Table 5a). The results indicated that lysine content was $(5.91 \mathrm{~g} / 100 \mathrm{~g}$ protein), while threonine was the lowest essential amino acid presented in the soybean and it was $(1.32 \mathrm{~g} / 100 \mathrm{~g}$ protein), but the highest percentage for essential amino acids was lysine $(5.91 \pm 0.18)$ followed by valine $(5.89 \mathrm{~g} / 100 \mathrm{~g}$ protein $)$. cysteine $\%$ was the lowest non-essential amino acid presented in the soybean and it was $(2.05 \mathrm{~g} / 100 \mathrm{~g}$ protein), but the highest percentage for non-essential amino acids was glutamic acid $(8.40 \mathrm{~g} / 100 \mathrm{~g}$ protein) followed by aspartic acid (8.32 $\mathrm{g} / 100$ g protein).

These results were consistent with Sharma et al. (2014) who reported that soybean seeds contain a large amount of all the essential amino acids, so it is a rich source of protein but lacks others such as methionine and cysteine. These seeds of different genotypes contain different amounts of amino acids where the proportions of methionine, sulfur and cysteine differed between different species. The results indicated that leucine was higher essential amino acid presented in the corn $(7.60 \mathrm{~g} / 100 \mathrm{~g}$ protein $)$, while lysine was the lowest essential amino acid and it was $(2.01 \mathrm{~g} / 100 \mathrm{~g}$ protein $)$. The non-essential amino acids were found in a wide range. Glutamic acid was the most predominant non-essential amino acid found and it was $(7.65 \mathrm{~g} / 100 \mathrm{~g}$ protein), followed by aspartic acid which was $(7.08 \mathrm{~g} / 100 \mathrm{~g}$ protein) However, the arginine was the lowest non-essential amino acid presented in the corn and it was $(3.64 \mathrm{~g} / 100 \mathrm{~g}$ protein).These results are consistent with Okaka (2005) who found that corn are deficient in sulphur amino acids such as lysine.

Results of amino acids composition for different blends of Doritos are shown in Table (5-b). From the obtained results, it could be illustrated that Doritos with corn/ S/PSR and corn /S/GS by 87/10/3\% contained a higher amount from all essential and non-essential amino acids than the blends of Doritos with corn only, Total essential amino acids in the Doritos blends ranged from 32.64 to $40.29 \mathrm{~g} / 100 \mathrm{~g}$ protein and non essential ranged from 46.33 to $54.56 \mathrm{~g} / 100 \mathrm{~g}$ protein, because the addition of soybean has increased the amount of amino acids. It is noticeable that the mixture of Doritos prepared from corn only is poor in the content of lysine, because the corn is poor in the content of sulfur amino acids such as lysine, therefore it was found that when making mixtures of corn with soybeans led to a high proportion of lysine as the legumes are rich in sulfur amino acids, These observation are in agreement with Okaka (2005). 
Table (5-b): Amino acids composition for different blends of corn chips (Doritos)

\begin{tabular}{|c|c|c|c|c|c|c|}
\hline $\begin{array}{c}\text { Amino acid } g / 100 \mathrm{~g} \\
\text { protein }\end{array}$ & $\begin{array}{c}\text { Control } \\
\text { (Corn100\%) }\end{array}$ & $\begin{array}{c}\text { Corn + } \\
\text { PSR } *(97+ \\
\text { 3\%) }\end{array}$ & $\begin{array}{c}\text { Corn + GS** } \\
(97+3 \%)\end{array}$ & $\begin{array}{c}\text { Corn / } \\
\text { S/PSR } \\
87 / 10 / 3\end{array}$ & $\begin{array}{c}\text { Corn /S/GS } \\
87 / 10 / 3\end{array}$ & $\begin{array}{c}\text { FAO } \\
\text { /WHO } \\
\text { Pattern } \\
(\mathbf{2 0 0 2 )}\end{array}$ \\
\hline \multicolumn{7}{|l|}{ Essential A.A. } \\
\hline Phenylalanine & 3.26 & 3.61 & 3.56 & 4.41 & 4.31 & 2.8 \\
\hline Histidin & 5.99 & 6.19 & 6.05 & 6.92 & 6.91 & 1.8 \\
\hline Isoleucin & 3.45 & 3.51 & 3.77 & 4.45 & 4.23 & 4.2 \\
\hline Leucine & 6.60 & 7.41 & 7.40 & 8.30 & 8.29 & 6.3 \\
\hline Lysine & 2.01 & 2.02 & 2.39 & 3.10 & 2.70 & 5.2 \\
\hline Methionine & 3.72 & 4.02 & 3.79 & 4.59 & 4.75 & 2.2 \\
\hline Threonine & 2.50 & 2.53 & 2.43 & 3.11 & 3.24 & 2.7 \\
\hline Valine & 5.12 & 5.11 & 4.27 & 5.89 & 5.86 & 4.2 \\
\hline Tryptophan & N.D. & N.D. & N.D. & N.D. & N.D. & \\
\hline $\begin{array}{l}\text { Total-essential A.A. } \\
\text { Non-essential }\end{array}$ & 32.64 & 34.40 & 33.66 & 40.77 & 40.29 & 29.4 \\
\hline Alanine & 4.42 & 4.38 & 4.51 & 5.35 & 5.22 & \\
\hline Aspartic Acid & 6.41 & 6.94 & 6.74 & 7.88 & 7.65 & \\
\hline Cysteine & 3.88 & 4.04 & 3.89 & 4.95 & 4.76 & \\
\hline Glutamic Acid & 7.65 & 7.79 & 7.73 & 8.90 & 8.62 & \\
\hline Glycine & 4.89 & 5.16 & 5.33 & 6.12 & 5.78 & \\
\hline Proline & 5.24 & 5.41 & 5.52 & 6.26 & 6.01 & \\
\hline Serine & 5.67 & 5.69 & 5.52 & 6.49 & 6.45 & \\
\hline Tyrosine & 4.52 & 4.75 & 4.55 & 5.76 & 5.54 & \\
\hline Arginine & 3.64 & 3.73 & 4.04 & 4.64 & 4.53 & \\
\hline Total non-essential a. a. & 46.33 & 47.89 & 47.83 & 56.35 & 54.56 & \\
\hline Total (TEAA + TNEAA) & 78.96 & 82.27 & 81.48 & 97.12 & 94.86 & \\
\hline $\begin{array}{l}\text { Ar EAA (Phe + } \\
\text { Tyrosine) }\end{array}$ & 7.78 & 8.36 & 8.11 & 10.17 & 9.85 & \\
\hline $\begin{array}{l}\text { TSAA(Methionine } \\
+ \text { +Cysteine) }\end{array}$ & 7.59 & 8.06 & 7.68 & 9.54 & 9.51 & \\
\hline
\end{tabular}

*(PSR): Pomegranate seeds residues and $* *(\mathrm{GS})$ guava seeds

N.D: Not Determined

Also, Jezierny et al. (2010) noted that when mixing grains with legumes, this leads to a balance in the amino acids content of these mixtures. Hess et al. (2016) reported that snacks are not highly nutritious and do not give the body nutrients. Therefore, this study aimed to make snacks containing many nutrients and acceptable. Leucine is the most concentrated essential amino acid, increased in both corn+PSR and corn+GS (7.41 and $7.40 \mathrm{~g} / 100 \mathrm{~g}$ protein, respectively) than Doritos with $100 \%$ corn $(6.60 \mathrm{~g} / 100 \mathrm{~g}$ protein). While lysine was the lowest essential amino acid presented and varied from 2.01 to 3.10, the highest percentage of lysine was in Doritos with (Corn/S/PSR)(3.10 g/100 g protein). Glutamic is the most concentrated non - essential amino acid. The highest was observed in corn/S/PSR $(8.90 \mathrm{~g} / 100 \mathrm{~g}$ protein) followed by Corn/S/GS (8.62 g/100 g protein), but the lowest value was found in the Doritos with $100 \%$ corn $(7.65 \mathrm{~g} / 100 \mathrm{~g}$ protein). As also shown in Table (5-b), it 
could be noted that Doritos with PSR, GS, soybean contained a much higher contents of phenylalanine, histidin, isoleucin, leucine, methionine, threonine, valine than the corresponding contents in the reference protein pattern of FAO/WHO (2002 ). On the other hand, the blends was found to be deficient in lysine and threonine. However, there has been an increase in soybean blends. Therefore, it is necessary to make different mixes to take advantage of different nutrients.

\section{Bioactive compounds and antioxidant activity for PSR,GS and soybean}

Bioactive compounds and antioxidant activity of PSR and GS are showed in Table (6-a). Our finding indicated that PSR has a significantly $(P \leq 0.05)$ higher amounts of polyphenols and total flavonoids (419.32 mg GAE/100 $\mathrm{g}$ and $93.12 \mathrm{mg}$ Rutin/100g, respectively) than GS (102.03 mg GAE/100 g and 53.99 $\mathrm{mg}$ Rutin/100g, respectively). On the other hand, GS contained a significantly $(P \leq 0.05)$ higher amounts of total carotenoids $(220.05 \mu \mathrm{g} / \mathrm{g})$ than PSR $(110.04$ $\mu \mathrm{g} / \mathrm{g}$ ). The results interpreted that antioxidants activity (DPPH) in PSR $(75.12 \%)$ were significantly $(P \leq 0.05)$ higher than GS $(50.14 \%)$. These results are in accordance with those reported by (Opute, 2008; EL-Safey et al. 2012 and Mekni et al. 2014). El Anany (2015) found that total flavonoids of guava seeds were $290.30 \mathrm{mg} / 100 \mathrm{~g}$ DW, phenolic content was $973.80 \mathrm{mg} / 100 \mathrm{~g} \mathrm{DW}$ and DPPH radical-scavenging activity expressed in \% inhibition was $63.74 \%$. Jain $\boldsymbol{e t}$ al. (2014) found that pomegranate seeds are rich in flavonoids, total phenols, total carotenoids. The results shows that the seeds can be used in more beneficial applications in food due to its rich content of unsaturated fatty acids, phenolic content and its antioxidant properties.

Table (6-a): Bioactive compounds and antioxidant activity for PSR and GS

\begin{tabular}{|c|c|c|}
\hline Component & *PSR & $* * \mathbf{G S}$ \\
\hline Polyphenols (mg of GAE/100 g) & $419.32 \pm 0.67^{a}$ & $102.03 \pm 0.40^{b}$ \\
\hline Total carotenoids ( $\mu \mathrm{g} / \mathrm{g}$ as beta-carotene ) & $110.04 \pm 0.37^{b}$ & $220.05 \pm 0.16^{\mathrm{a}}$ \\
\hline Total flavonoids (mg of Rutin/100g) & $93.12 \pm 0.88^{a}$ & $53.99 \pm 0.90^{b}$ \\
\hline DPPH scavaning activity (\%) & $75.12 \pm 0.61^{\mathrm{a}}$ & $50.14 \pm 0.51^{b}$ \\
\hline
\end{tabular}

Data was expressed using Mean \pm SD. The same letter in a row are not significantly different at $P \leq 0.05$.

Pairwise comparison bet. each 2 groups was done using Least significant difference (LSD)

* (PSR) Pomegranate seeds residues ** (GS) guava seeds.

The average of DPPH and total phenolic content for soybean were (63.90 $\%$ and $576.0 \mathrm{mg} \mathrm{GAE} / 100 \mathrm{~g}$ ) as shown in Table (6-b). The antioxidant activity of soybeans was in correlation with total phenols content (Kumar et al., 2010a). Sharma et al. (2014) found that the content of total phenols, orthodihydroxy phenols and flavonols in different genotypes ranged from 1.0-1.5, 
$0.10-0.21$ and $0.20-0.34 \mathrm{mg} \mathrm{g}-1$, respectively. Soybean content of phenolic compounds varies from place to place and from region to region. This is confirmed by the study carried out by Chung et al. (2011) who found that the total phenolic content in Korean soybean was $366 \mathrm{mg} / 100 \mathrm{~g}$, while Malenčić $\boldsymbol{e t}$ al. (2007) found a different ratio in Serbia where total phenolic content ranged from 270 to $488 \mathrm{mg} / 100 \mathrm{~g}$.

The total isoflavones content of soybean was $372.0 \mathrm{mg} / 100 \mathrm{~g}$. The highest average value of glycitein was found at $(170.4 \mathrm{mg} / 100 \mathrm{~g})$ while, genistein had the lowest value at $(60.10 \mathrm{mg} / 100 \mathrm{~g})$. Soybeans are a major source of isoflavones in human nutrition where they are found in large quantities, while in cereals and legumes in a small amount (Fletcher, 2003). Some studies found that plasma genistein and daidzein concentrations were very high after about six hours of taking isoflavones. These compounds also appeared, but less frequently after one hour of eating a soy-rich meal (Franke et al., 2014). Mujić et al. (2011) found that total isoflavones content ranging from 80.7 to $213.6 \mathrm{mg} / 100 \mathrm{~g}$ in various soybean cultivars. Carrão-Panizzi and Kitamura (1995) reported that some researchers found isoflavones in different soybean varieties and their concentration ranged between 126.1 and $409.2 \mathrm{mg} / 100 \mathrm{~g}$. Isoflavones are good ingredients for human health as they prevent many diseases such as osteoporosis, menopausal symptoms and heart diseases (Zaheer and Humayoun, 2017).

\begin{tabular}{lc} 
Table (6-b): Bioactive compounds and antioxidant activity for soybean \\
\multicolumn{1}{c}{ Soybean } & Values \\
\hline DPPH (\%) & $63.90 \pm 0.42$ \\
TPC mg GAE/100 g & $576.0 \pm 0.32$ \\
Content of isoflavone (mg/100 g of soybean) & \\
Daidzein & $141.5 \pm 0.14$ \\
Glycitein & $170.4 \pm 0.19$ \\
Genistein & $60.10 \pm 0.84$ \\
Total & $372.0 \pm 1.18$ \\
\hline
\end{tabular}

Values represent means of triplicates. Data was expressed using Mean \pm SD.

Anti-nutritional factors and protein digestibility of PSR, GS, corn, soybean and different blends of corn chips (Doritos)

Anti-nutritional factors and protein digestibility of PSR,GS, corn and soybean are illustrated in Table (7). The significantly $(P \leq 0.05)$ higher amount of trypsin inhibitors and phytic acid were found in GS (41.98 and 72.02, respectively) compared to PSR (22.02 and 14.01, respectively). On the other hand, protein digestibility in PSR were significantly $(P \leq 0.05)$ higher $(90.08 \%)$ than GS $(80.99 \%)$. The reduction of anti-nutrients may have a role in protein digestibility improvement (Laminu et al., 2011). Anti-nutrients are a double- 
edged sword as they have both adverse effects and health benefits, such as phytic acid, which binds with calcium, copper, iron and zinc and forms insoluble complexes. Flavonoids are widespread forms of anti-nutrients and a group of polyphenols that include phenolic compounds (tannins), saponins and enzyme inhibitors (proteases and amylase) (Reyden and Selvendran 1993). El Anany (2015) determined the content of phytic acid and tannins from guava seeds and found the results were as follows: (273.63 and $325.67 \mathrm{mg} / 100 \mathrm{~g}$, respectively) on dry weight basis.

Table (7): Anti-nutritional factors and protein digestibility of PSR, GS, corn, soybean and different cooked blends of corn chips (Doritos)

\begin{tabular}{|c|c|c|c|c|}
\hline & Components & $\begin{array}{c}\text { Trypsin } \\
\text { inhibitor } \\
\text { (TIU/mg) }\end{array}$ & $\begin{array}{l}\text { Phytic acid } \\
(\mathrm{mg} / 100 \mathrm{~g})\end{array}$ & $\begin{array}{c}\text { Protein } \\
\text { digestibility } \\
(\%)\end{array}$ \\
\hline \multirow{4}{*}{ Raw materials } & *PSR & $22.02 \pm 0.23^{b}$ & $14.01 \pm 0.56^{\mathrm{b}}$ & $90.08 \pm 0.46^{\mathrm{a}}$ \\
\hline & GS & $41.98 \pm 0.003^{\mathrm{a}}$ & $72.02 \pm 0.07^{\mathrm{a}}$ & $80.99 \pm 0.21^{b}$ \\
\hline & $* *$ Soybean & $0.63 \pm 0.43^{\mathrm{a}}$ & $9.26 \pm 0.37^{\mathrm{a}}$ & $85.46 \pm 0.32^{a}$ \\
\hline & Corn & $0.52 \pm 0.10^{\mathrm{b}}$ & $4.96 \pm 0.73^{b}$ & $79.02 \pm 0.53^{b}$ \\
\hline \multirow{5}{*}{$* * *$ Doritos blends } & Control (corn \% 100) & $1.80 \pm 0.37^{\mathrm{a}}$ & $7.41 \pm 0.61^{\mathrm{a}}$ & $78.87 \pm 0.68^{d}$ \\
\hline & Corn + PSR $(97+3 \%)$ & $1.16 \pm 0.39^{b}$ & $5.67 \pm 0.71^{\mathrm{b}}$ & $80.35 \pm 0.34^{c}$ \\
\hline & Corn + GS $(97+3 \%)$ & $1.76 \pm 0.10^{\mathrm{a}}$ & $6.97 \pm 0.13^{\mathrm{a}}$ & $79.08 \pm 0.33^{d}$ \\
\hline & Corn / S/PSR 87/10/3 & $0.48 \pm 0.35^{\mathrm{c}}$ & $4.25 \pm 0.26^{c}$ & $90.15 \pm 0.40^{\mathrm{a}}$ \\
\hline & Corn /S/GS 87/10/3 & $1.13 \pm 0.19^{b}$ & $5.23 \pm 0.27^{b}$ & $83.03 \pm 0.78^{b}$ \\
\hline
\end{tabular}

Data was expressed using Mean \pm SD. (PSR) Pomegranate seeds residues, (GS) guava seeds.

Pairwise comparison bet. each 2 groups was done using Least significant difference (LSD).

*Means in the same column in PSR and GS are not significant (i.e. Means with Different letters are significant)

**:Means in the same column in Corn and Soybean are not significant (i.e. Means with Different letters are significant)

***Means in the same column in Doritos blends are not significant (i.e. Means with Different letters are significant)

Results of anti-nutritional factors of phytic acid and trypsin inhibitors showed that soybean contained a significant $(P \leq 0.05)$ increase of phytic acid, trypsin and protein digestibility $(9.26,0.63$ and 85.46 , respectively) compared to those of corn (4.96, 0.52 and 79.02, respectively). Phytic acid is a form of phosphorus stored in plants. It is also an anti-nutrient because it is strongly linked to starch, protein and minerals, which leads to reduce the bioavailability (Weaver and Kannan, 2002). The soybean genotypes ' phytic acid content ranged from 2.3 to $5.6 \mathrm{mg}$ g-1 (Sharma et al., 2014). The range of antinutritional factors for phytic acid and phenols was stated to be 1.6-3.1 and 18.3-35 mg g-1, respectively in soybean (El-Emery and Amin 2010). Guillamon et al. (2008) found that trypsin inhibitor among legume seeds can be found in very small quantities as in Lupinus spp, on the contrary, it may be found in other types in large quantities such as glycine max cultivars. On the other hand, Kumar et al. (2003) found that the amount of trypsin inhibitors in defatted soy flour ranged between 42 and $113 \mathrm{mg}$ g-1, and trypsin inhibitors activity did not change due to location change. Cereal seeds contain about $1-2 \%$ 
by weight of phytic acid and may increase this percentage to 3-6\% (Gupta $\boldsymbol{e t}$ al., 2015).

Anti-nutrition factors including phytic acid and trypsin inhibitor for different blends are presented in Table (7). Concentrations of phytic acid and trypsin inhibitor among the Doritos blends were significantly different $(P \leq 0.05)$. Phytic acid in the formulated Doritos ranged from 4.25 to 7.41 $\mathrm{mg} / 100 \mathrm{~g}$. The Doritos with $100 \%$ corn had the highest value $(7.41 \mathrm{mg} / 100 \mathrm{~g})$. The lowest value of phytic acid in the Doritos with Corn/S/PSR (87/10/3\%) with value $4.25 \mathrm{mg} / 100 \mathrm{~g}$. These results are in agreement with Sade (2009) who found that preparation methods can reduce the phytic acid content in food.

The value of trypsin inhibitor in the formulated Doritos blends is varied between 0.48 to $1.80 \mathrm{TIU} / \mathrm{mg}$, these low values are mainly due to cooking and roasting processes as trypsin inhibitor can partially change their nature when exposed to high temperature. This is in agreement with Leeson and Summers (2008) who found that the time of exposure to heat directly affects the trypsin inhibitors that are found in raw soybeans where they are destroyed, and they also found that high heat for a shorter period of time have the same effect when exposed to low temperatures for longer periods. Also, Hefnawy (2011) reported that microwave cooking destroyed trypsin inhibitors to a degree similar to those observed in six legumes cooked using the traditional methods.

In the present study, it was found that roasting reduced anti-nutritional factors, which is consistent with the results of the study by Adeyemo (2013) who found that roasting reduces the content of trypsin inhibitor from 1.20 to $0.025 \mathrm{mg} / \mathrm{gm}$, phytates content from 1.6 to $0.25 \mathrm{mg} / \mathrm{g}$. Also, he reported that cooking reduced, but not as much as roasting, the anti-nutritional factors. This shows that the amount of anti-nutritional present after preparation and cooking in Doritos blends was safe for human nutrition and was found in a proportion that does not cause any side effects, according to Kumar et al. (2010b).

The protein digestibility of the formulated Doritos blends was varied between $78.87 \%$ for Doritos with $100 \%$ corn to $90.15 \%$ for corn/soybean/ PSR $(87 / 10 / 3)$ blend. The studied formulated Doritos blends have good digestibility because their values were higher than $75 \%$.

It is noticeable that protein digestibility in soybean blends was higher than only seeds blends. In addition, the reduced amount of anti-nutritional factors has led to an improvement in protein digestion. This is consistent with Gilani $\boldsymbol{e t}$ al. (2005) who observed that high levels of dietary trypsin inhibitors from grain and legumes caused decreases in amino acids digestibility and protein in living systems of up to 50 percent. 


\section{CONCLUSION}

Based on the results obtained, it can conclude that guava and pomegranate seeds powder contain many nutrients such as protein, fiber, minerals, fatty acids and various antioxidants, in addition to low caloric content. Also, they can be used in food enrichment to compensate the shortage of amino acids, decreasing of anti-nutritional factors and improvement of protein digestibility. Therefore, it can be used as one of the ingredients to produce new food products that are suitable for human nutrition, have good acceptance and help in reducing many diseases, and it also helps in preserving the environment as a result of benefiting from these wastes. However, it is suggested that further studies be conducted to see how these wastes are used.

\section{REFERENCES:}

AACC. 1995. American Association of Cereal Chemists. Cereal Laboratory Method American Association of Cereal Chemists, Inc, St. Paul, Minnesota, USA.

Abd-El Haleem, M. E. A. 2016. Evaluation and Application of Some Phytochemicals in Pomegranate Seed Residues and Guava Seeds. Alex. J. Fd. Sci. \& Technol. 13, 1: 19-30.

Adeyemo, S. M. and Onilude, A. A. 2013. Enzymatic Reduction of Antinutritional Factors in Fermenting Soybeans by Lactobacillus plantarum Isolates from Fermenting Cereals. NIFOJ, 31 (2): 84 - 90.

Adhami, V. M. and Mukhtar, H. 2006. Polyphenols from green tea and pomegtanate for prevention of prostate cancer. Free Radical Research, 40: $1095-1104$.

Aly, A. 2019. Chemical, Rheological, Sensorial and Microbial Evaluation of Supplemented Wheat Flour Biscuit with Guava Seeds Powder. J. Food and Dairy Sci., Mansoura Univ., 10 (5): 147 - 152.

Ander, B. P., Dupasquier, C. M., Prociuk, M. A. and Pierce, G. N.. 2003. Polyunsaturated fatty acids and their effects on cardiovascular disease. Exp Clin Cardiol. Winter, 8(4): 164-172.

AOAC. 1990. Official Methods of Analysis. Association of Official Analytical Chemists 15th, Ed, Washington, D.C. USA.

AOAC. 2000. Official Methods of Analysis of AOAC International. 17th ed. Gaithersburg, Maryland, USA.

AOAC. 2007. Determination of fat, moisture, and protein in meat and meat products by using the FOSS Food Scan near-infrared spectrophotometer with FOSS artificial neural network calibration model and associated database: collaborative study. Journal of AOAC International 90 (4):1073-1083. 
Bakal, H., Gulluoglu, L., Onat, B. and Arioglu, H. 2017. The Effect of growing seasons on some agronomic and quality characteristics of soybean vaireties in mediterranean region in turkey. Turk $\mathbf{J}$ Field Crops, 22(2): 187-196.

Brasil, 2005. Ministry of Health. National Health Surveillance Agency (ANVISA). RDC Resolution no. 269. Technical Regulation on Recommended Daily Intake (IDR) of Protein, Vitamins, and Minerals. Official Gazette of the Federative Republic of Brazil.

Carrão-Panizzi, M. C. and Kitamura, K. 1995. Isoflavone Content in Brazilian Soybean Cultivars. Breeding Science, 45(3): 295-300.

Chaudhary, N. and Tripathi, S. 2014. A review on multipurpose plant: psidiumguajava. International Journal of Pharmacology and Phytochemical Research, 6:118-121.

Choi, M. H., Kima, G. H. and Lee, H.S. 2002. Effectsof ascorbic acid retention on juice color andpigment stability in blood orange (Citrus sinensis) juice during refrigerated storage. Food ResearchInternational, 35(8):753-759.

Chung, I. M., Seo, S. H., Ahn, J. K. and Kim, S. H. 2011. Effect of processing, fermentation, and aging treatment to content and profile of phenolic compounds in soybean seed, soy curd and soy paste. Food Chemistry, 127(3): 960-967.

Coradi, P., Fernandes, C. P., Helmich, J. C., and Gonelik, A. D. 2016. Effects of drying air temperature and grain initial moisture content on soybean quality (Glycine max (L.) merrill). Eng. Agríc., Jaboticabal, 36, (5): 866-876.

Dahdouha, S., Grandeb, F., Espinosab, S. N., Vincentb, A., Gibsonc, R., Baileyc, K., Kingd, J., Rittenschoberb, D. and Charrondièreb, U. R. 2019. Development of the FAO/INFOODS/IZINCG Global Food Composition Database for Phytate. Journal of Food Composition and Analysis, 78: 42-48.

El Anany, A. M. 2015. Nutritional composition, antinutritional factors, bioactive compounds and antioxidant activity of guava seeds (PsidiumMyrtaceae) as affected by roasting processes. J Food Sci Technol, 52(4): 2175-2183.

El-Emery, G., A. E. and Amin, A. Y. 2010. Assessment level of some antinutritional and nutritional factors in some Egyptian cultivated soybean and barley. Res J AgricBiolSci, 6:481-486.

Elfalleh, W., Tlili, N. Nasri, N. Yahia, Y. Hannachi, H. Chaira, N. Ying, M. and Ferchichi, A. 2011. Antioxidant capacities of phenolic compounds and tocopherols from Tunisian pomegranate (Punicagranatum) fruits. J. Food Sci., 76 (5): 707-713. 
El-Nemr, S. E., Ismail, I. A. and Ragab, M. 1990. Chemical composition of juice and seed of pomegranate fruit. Die Nahrung, 34:601-606.

El-Safey, F.S., Salem, R. and El-Ghang, M. E. 2012. Nutritional evaluation of different seed flours as novel sources of protein. Chemical and World Journal of Dairy and Food Sciences, 7: 59-65.

FAO/WHO. 1991. Protein quality evaluation. Reports of a joint FAO/WHO Expert Consultation, Food and Agriculture Organization of the United Nations, FAO, Rome, Food and Nutrition, 51: 1-66.

FAO/ WHO/ UNU. 2002. Expert Consultation on Protein and Amino Acid Requirements in Human Nutrition, Geneva. Switzerland.

Fernandez -Pachon. M. S., Villano, D., GarcyiaParrilla, M. C. and Troncoso, A. M. 2004. AnAtioxidant activity of wines and relation with their polyphenolic composition. Analytica Chimica Acta, 513: 113-118.

Fletcher, R. J. 2003. Food sources of phyto-oestrogens and their precursors in Europe. Br J Nutr.;89Suppl 1:S39-43.

Fontanari, G. G., Jaco, M. C., Souza, G. R., Batistuti, J. P., Neves, V. A., Pastre, I. A., and Fertonanim, F. L. 2008. DSC studies on protein isolate of guava seeds Psidiumguajava. Journal of Thermal Analysis and Calorimetry, 93(2): 397-402.

Franke, A. A., Lai, J. F. and Halm, B. M. 2014. Absorption, distribution, metabolism, and excretion of isoflavonoids after soy intake. Arch Biochem Biophys, 559:24-28.

Gao, X., Cui, C. and Ren, J. 2011. Changes in the chemical composition of traditional Chinese-type soy sauce at different stages of manufacture and its relation to taste. International Journal of Food Science and Technology, 46: 243-249.

Gilani, G. S., Cockell, K. A. and Sepehr E. 2005. Effects of antinutritional factors on protein digestibility and amino acid availability in foods.J AOAC Int, 88 (3): 967-87.

Gitelson, A. A., Merzlyak, M. N. and chivkunova, O. B. 2001. Optical properties and non- destructive estimation of flavonoids content in plant leaves. Journal of Photochemistry and Photobiology, 74: 38-45.

Gondim, J. A. M., Moura, M. F. V., Dantas, A. S., Medeiros, R. L. S. and Santos, K. M. 2005. Composição centesimal e de mineraisemcascas de frutas. RevistaCiênciaTecnologia de Alimentos, 25(4): 825-827.

Guillamon, E., Pedrosa, M. M., Burbano, C., Cuadrado, C. and Muzquiz, M. 2008. The trypsin inhibitors present in seeds of different grain legume species and cultivar. J Food Chem, 107: 68-74. 
Gupta, R. K., Gangoliya, S. S. and Singh, K. 2015. Reduction of phytic acid and enhancement of bioavailable micronutrients in food grains. J Food Sci Technol, 52(2):676-684.

Guria, P. 2006. Phisico-chemical properties, nutritional quality and value addition to quality protein maize (Zea mays L.). Master of home science. University of Agricultural Sciences, Dharwad.

Hambidge, K. M., Krebs, N. F., Westcott, J. L., Sian, L., Miller, L. V., Peterson, K. L. and Raboy, V. 2005. Absorption of calcium from tortilla meals prepared from low-phytate maize. Am J ClinNutr, 82: $84-87$.

Hea, L., Zhanga, X., Hua, H., Chao, X., Yuana, F., Knezb, Z. E., Novakb, Z. and Yanxiang, G. 2014. Subcritical water extraction of phenolic compounds from pomegranate (Punicagranatum L.): seed residues and investigation into their antioxidant activities with HPLC-ABTS Assay. Journal of Agricultural and Food Chemistry, 62: 3550-3556.

Hefnawy, T.H. 2011. Effect of processing methods on nutritional composition and anti-nutritional factors in lentils (Lens culinaris). Annals of Agricultural Sciences, 56, (2): 57-61.

Hess, J. M., Jonnalagadda, S. S. and Slavin, J. L. 2016. What Is a Snack, Why Do We Snack, and How Can We Choose Better Snacks? A Review of the Definitions of Snacking, Motivations to Snack, Contributions to Dietary Intake, and Recommendations for Improvement. Adv Nutr, 7(3): 466-475.

Hooda, S. and Jood, S. 2005. Organoleptic and nutritional evaluation of wheat biscuits supplemented with untreated and treated fenugreek flour. Food Chemistry, 90(3):427-435.

Isaac, A. T. and Koleosho, A. 2012. Effects of Processing Method on the Nutrients' Composition of Maize/Soya Complementary Food. J. Pharm. Biol. Sci, 4(1):39-43.

Jain, S. R., Rai, A. R., Upadhyaya and Malhotra, G. 2014. "Punicagranatum: a natural and recent approach towards dental problem," International Journal of Pharmaceutical Sciences and Research, 2, (1): 1-6.

Jezierny, D., Weiss, E. and Mosenthin, R. 2010. The use of grain legumes as a protein source in pig nutrition: A review. Animal Feed Science and Technology, 157(3):111-128.

Kakaei, K., Noshad, M., Nasehi, B., Hojjati, M. and Beiraghi-Toosi, S. 2019. Optimization of Physicochemical Characteristics of Corn-Based Extruded Snacks Containing Pomegranate Seed Powders. Nutrition and Food Sciences Research, 6, 1,:35-40. 
Kirkpatrick, L.A. and Feeney, B.C. 2013. A simple guide to IBM SPSS statistics for version 20.0. Student ed, Wadsworth, Cengage Learning, Belmont, Calif,.

Kotz, S., Balakrishnan, N., Read, C.B. and Vidakovic, B. 2006. Encyclopedia of statistical sciences, 2nd edn, Wiley-Interscience, Hoboken, N.J.

Kumar, K. P. V., Pillai, M. S. N. and Thusnavis, G. R. 2011. Seed extract of $\mathrm{P}$ sidiumguajava as ecofriendly corrosion inhibitor for carbon steel in hydrochloric acid medium. J Mater Sci Technol, 27(12):1143-1149.

Kumar, V., Rani, A., Dixit, A. K., Pratap, D. and Bhatnagar, D. 2010 a. A comparative assessment of total phenolic content, ferric reducing-antioxidative power, free radical-scavenging activity, vitamin $\mathrm{C}$ and isoflavones content in soybean with varying seed coat colour, Food Res. Int, 43: 323-328.

Kumar, V., Sinha, A. K., Makkar, H. P. S. and Becker, K. 2010 b. Dietary roles of phytate and phytase in human nutrition: A review. Food Chemistry, 120: 945-959.

Kumar, V., Rani, A., Solanki, S. and Hussani, S.M. 2006. Influence of growing environment on the biochemical composition and physical characteristics of soybean seed. Journal of Food Composition and Analysis, 19: 188-195.

Kumar, V., Rani, A., Tindwani, C. and Jain, M. 2003. Lipoxygenaseisozymes and trypsin inhibitor activities in soybean as influenced by growing location. Food Chem, 83:79-83

Laminu, H. H., Modu, S. and Numan, A. 2011. Production, In vitroprotein digestibility, phytate content and acceptability of weaning food from pearl millet and cowpea. Int. J. of Nutr. andMetabolsm, 3(3): 22-30.

Leeson, S. and Summers, J. D. 2008. Comercial Poultry Nutrition, Nottingham University Press, ISBN 978-1-904761-78-5, Guelph, Ontario.

Lin, Y. H. and Chen, H. J. 1989. Relationship between trypsin inhibitor activity and water soluble protein and cumulative rainfall in sweet potatoes. Journal of the American Society for Horticultural Science, 114: 418-818.

Liu, G., Xu, X. Hao, Q. and Gao, Y. 2009. Supercritical CO2 extraction optimization of pomegranate (Punicagranatum L.) seed oil using response surface methodology. LWT-Food Science and Technology, 42: 1491- 1495.

Malenčić, D., Popović, M. and Miladinović, J. 2007. Phenolic content and antioxidant properties of soybean (Glycine max (L.) Merr.) seeds. Molecules, 12(3): 576-581. 
Martínez, R., Torres, A., Meneses, M. A., Figueroa, J. G., Pérez-Álvarez, J. A. and Viuda-Martos, M. 2012. Chemical, technological and in vitro antioxidant properties of mango, guava, pineapple and passion fruit dietary fibre concentrate. Food Chemistry, 135(3): 1520-1526.

Mekni, M., Dhibi, M. karroubi, W., Hmida R. B.,Cherail, I. and Hammane, M. 2014. Natu-t ral conjugated and trans-fatty acids in seed oils and phytochemicals in extracts issued from three Tunisian pomegranate (punicagranatum.L) cultivars. International Journal of Current Microbiology and Applied Sciences, 3: 778-782.

Melanson, K. J., Angelopoulos, T.J., Nguyen, V.T., Martini, M. Zukley, L. Lowndes, J. Dube, T.J., Fiutem, J.J., Yount, B.W. and Rippe, J.M. 2006. Consumption of whole-grain cereals during weight loss: effects on dietary quality,dietary fiber, magnesium, vitamin B 6, andobesity, J. Am. Diet. Assoc, 106:1380-1388.

Miller, D. D. 2008. Minerals. In:Damodaran S, Perkin KL and OR Fennema (Eds.). 4th Edition. Fennema's Food Chemistry. CRC Press, Boca Raton, FL: 523- 569.

Montonen, J., Knekt, P. Jarvinen, R. Aromaa, A. and Reunanen, A. 2003. Whole-grain and fiber intake and the incidence of type 2 diabetes. Am. J.Clin.Nutr, 77: 622-629.

Mourouti, N., Kontogianni, M. D., Papavagelis, C. saltopoulou, T. P., Kapetanstrataki, M.G., Plytzanopoulou, P., Vassilakou, T., Malamos, N., Linos, A. and Panagiotakos, D.B. 2016. Whole grain consumption and breast cancer: a case-control study in women. J.Am.Coll.Nutr, 35:143-149.

Muir, J. G., Yeow, E.G.W., Keogh, J., Pizzey, C., Bird, A. R., Sharpe, K. Dea, K. O. and Macrae, F. A. 2004. Combining wheat bran with resistant starch has more beneficial effects on fecal indexes than does wheat bran alone. Am. J. Clin.Nutr, 79 (6):1020-1028.

Mujić, I., Šertović, E., Jokić, S., Sarić, Z., Alibabić, V., Vidović, S. 2011. Isoflavone content and antioxidant properties of soybean seeds. Croatian Journal of Food Science and Technology; 3(1): 16-20.

Nicanor, A. B., Moreno, A.O. Ayala, A. L. M. and Ortiz, G.D. 2000. Guava seed protein isolate: Functional and nutritional characterization. J. Food Biochem., 25: 77-90.

Okaka, J. C. 2005. Basic Processing of Grain Cereals and Legumes in Handling, Storage and Processing of Plant Foods. OCJ Academic Publishers, Enugu, Nigerian: 30-60.

Opute, E. I. 2008. The component and fatty acids of psidiumguajava seeds. Journal of the Science of Food and Agriculture, 59: 737-742. 
Prakash, V., and Prakash, J.1999. In vitro protein digestibility of legumes cooked with spices. Food/Nahrung, 43(1):19-21.

Prasad, N. B. and Azeemoddin, L. G. 1994. Characteristics and composition of guava (PsidiumguajavaL.) seed and oil. J Am Oil ChemSoc, 71(4): 457-458.

Prasanthi, P. S., Naveena, N., Vishnuvardhana Rao, M. Bhaskarachary, K. 2017. Compositional variability of nutrients and phytochemicals in corn after processing. J Food Sci Technol, 54(5):1080-1090.

Radwan, S. S. 1978. Coupling of two dimensional thin layer chromatography with gas chromatography for the quantitative analysis of lipid classes and their constituent fatty acids. Journal of Chromatographic Science, 16:538-542.

Raihana, N. R., Marikkar, N. M., I. Amin, I. M. and Shuhaimi, M. 2015. A Review on Food Values of Selected Tropical Fruits' Seeds. International Journal of Food Properties, 18, (11): 2380-2392.

Rashwan, O. A. A. and Mohamady, M. F. 2015. Nutritional value and microbiological profile of some locally prepared weaning-food mixtures. Egypt. J. of Nutrition and Health, 10 (1): 1-14.

Reyden, P. and Selvendran, R. R. 1993. Phytic acid: properties and determination. In: Macrae R, Robinson RK, Sadler MJ, (eds). Encyclopedia of food science, food technology and nutrition. London: Academic Press: pp. 3582-3587.

Riaz, M. N. 2016. Snack Foods, Processing. Reference Module in Food Science.

Rowayshed, G., A., Salama, M., Abul-Fadl, S. Akila-Hamza and Emad, A. M. 2013. Nutritional and Chemical Evaluation for Pomegranate (Punicagranatum L.) Fruit Peel and Seeds Powders By Products. Middle East Journal of Applied Sciences, 3(4): 169-179.

Sade, F.O. 2009. Proximate, antinutritional factors and functional properties of processed pearl millet. Journal of Food Technology,7 (3):92-97.

Seo, J. S., Sohn, H. B., Noh, K., Jung, C., An, J. H., Donovan, C. M., Somers, D. A., Kim, D. I., Jeong, S., Kim, C., Kim, H. M., Lee, S., Choi, Y. D., Moon, T. W., Kim, C. H. and Cheong, J. 2012. Expression of the Arabidopsis AtMYB44 gene confers drought/saltstress tolerance in transgenic soybean. Mol Breeding, 29: 601-608.

Sharma, S., Kaur, M., Goyal, R. and Gill, B. S. 2014. Physical characteristics and nutritional composition of some new soybean (Glycine max (L.) Merrill) genotypes. J Food Sci Technol, 51(3):551-557.

Thuzar, M. 2010. The Effects of Temperature Stress on the Quality and Yield of Soya Bean [(Glycine max L.) Merrill.] Journal of Agricultural Science, 2 (1): 172-179. 
Tsangalis, D., Ashton, J. F., Mcgill, A.E.J. and Shah, N.P. 2002. Enzymic Transformation of Isoflavone Phytoestrogens in Soymilk by $\beta$ Glucosidase- Producing Bifidobacteria, J. Food Sci, 67: 3104- 3113.

Uchôa, A. M. A., Costa, J. M. C., Maia, G. A., Silva, E. M. C., Carvalho, A. F. F. U. and Meira, T. R. 2008. Parâmetrosfísico-químicos: teor de fibrabruta e alimentar de pósalimentíciosobtidos de resíduos de frutastropicais. SegurançaAlimentar e Nutricional, 15(2): 58-65.

Uchôa-thomaz A. M. A., Sousa, E. C., Carioca, J. O. B., Morais, S. M. D., Lima, A. D., Martins, C. G.,, Alexandrino, C. D. Ferreira, P. A. T., Rodrigues, A. L. M., Rodrigues, S. P., Thomaz, J. C. D. A., Silva, J. D. R. and Rodrigues L. L. 2014. Chemical composition, fatty acid profile and bioactive compounds of guava seeds (Psidiumguajava L.). Food SciTechnol, 34:485-492.

Weaver, C. M. and Kannan, S. 2002. Phytate and mineral bioavailability. In: Sathe, Reddy SK (eds) Food phytates. CRC, Boca Raton: 211-224.

Wheeler, E. L.and Ferrel, R. E. 1971. A method of phytic acid determination in wheat. Cereal Chemistry, 48: 312-316.

World Health Organization - WHO. 2013. Review and updating of current WHO recommendations on salt/sodium and potassium consumption. Geneva.

Wu, S. and Tian, L. 2017. Diverse phytochemicals and bioactivities in the ancient fruit and modern functional food pomegranate (Punicagranatum). Molecules, 22 (10):1606.

Yagcl, S. and Gogus, F. 2008. Response surface methodology for evaluation of physical and functional properties of extruded snack foods developed from food-by-products. Journal of Food Engineering, 86(1):122-32.

Zaheer, K. and Humayoun, A. M. 2017. An updated review of dietary isoflavones: Nutrition, processing, bioavailability and impacts on human health. Critical Reviews in Food Science and Nutrition, 57(6):1280-1293.

Zaini, N. A., Anwar, M., Abdul Hamid, F., Saari, A. and Kundur, N. 2011. Benincasahispida (Thunb.) Cogn.]: A potential source for valuable nutrients and functional foods. Food Research International, 44 (7): 2368-2376.

Zambrano, F., Despinoy, P., Ormenese, R. and Faria, E.V. 2004. The use of guar and xanthan gums in the production of 'light' low fat cakes. International Journal of Food Science \& Technology, 39 (9): 959-966.

Zhang, Y., Song, Q., Yan, J., Tang, J., Zhao, R., Zhang, Y., He, Z., Zou, C. and Ortiz-Monasterio I. 2010. Mineral element concentrations in grains of Chinese wheat cultivars. Euphytica. 174 (3):303-313. 


\section{ABSTRACT \\ Utilization of pomegranate and guava seeds in the manufacture of corn chips (Doritos) enriched with soybeans}

There is an increase interest in the modern era by individuals, dietitians and researchers on the utilization of fruit wastes which contain many healthbeneficial nutrients and how to incorporate them into some acceptable products for use in overcoming modern-day diseases. This study aims to prepare high quality functional corn chips (Doritos) from some unused fruit wastes with the addition of soybeans, at low cost and high nutritional value. Corn chips were produced from the mixture of corn flour with some seeds powder (guava and pomegranate seeds) and one type of legumes (soybean). Blends were prepared in a different ratios corn $100 \%$, corn + GS $(97+3 \%)$, corn+PSR $(97+3 \%)$, corn+S+GS $(87+10+3 \%)$ and corn + S+PSR $(87+10+3 \%)$ using traditional techniques like drying, milling and roasting. Then, sensory evaluation, chemical composition, fatty acids, amino acids, antioxidant activity, anti-nutritional factors and protein digestibility were determined in samples. The results of the sensory evaluation showed that the best acceptance was for the blend containing corn / soybean / pomegranate seeds and the following corn / guava seeds blend, however the control sample prepared with $(100 \%$ corn) remained more acceptable compared to the other blends. Also, The results showed that guava seeds, pomegranate seeds, corn and soybean were rich in many nutrients such as protein, minerals, fatty acids, fibers and antioxidant components. As a result, the protein content, crude fiber and minerals content of the corn chips "Doritos" showed a significantly improvement with the addition of seeds and soybean flour compared to the control sample. The amino acids content of corn chips 'Doritos', increased especially with the addition of soybean. Also, the addition of seeds and soybean flour with heat treatment reduced the amount of antinutritional factors, while there was an increase in protein digestibility in blends compared to control Doritos. In conclusion, seeds powder of guava, pomegranate and soybean can be used as one of the ingredients to prepare new food products that are suitable for human nutrition, have good acceptance, help in reducing many diseases and they also help in preserving the environment as a result of using these wastes.

Keywords: Corn flour, guava seeds, pomegranate seeds, soybean, sensory evaluation, chemical composition, amino acids, anti-nutritional factors and protein digestibility. 


\section{ملخص البحث}

\section{الاستفادة من بذور الرمان والجوافة في صناعة رقائق ذرة (دوريتوس) معزز بفول الصويا}

هناك اهتمام منزايد فى العصر الحديث من قبل الأفراد وأخصائيي التغذية والباحثين حول استخدام مخلفات الفاكهة التي تحتوي على العديد من العناصر الغذائية الصحية المفيدة وكيفية دمجها في بعض المنتجات المقبولة لاستخدامها في التغلب على أمراض العصر الحديث. تهدف هذه الدراسة

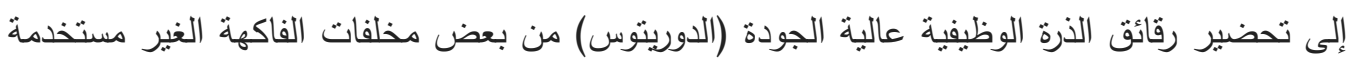

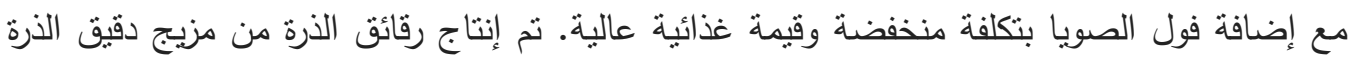
مع مسحوق بعض البذور (بذور الجوافة والرمان) ونوع واحد من البقوليات (فول الصويا). تم تحضير

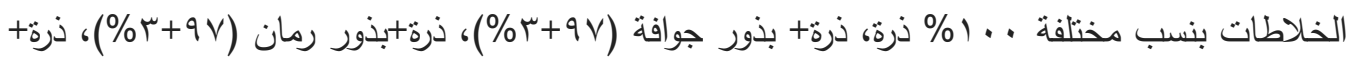

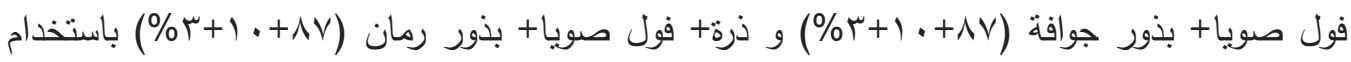
التقنيات التقليدية مثل التجفيف والطحن والتحميص ـبعد ذللك تم تقدير التقيبم الحسي ، التركيب الكيميائي

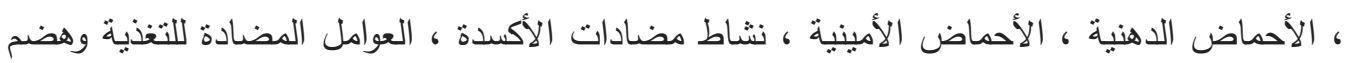

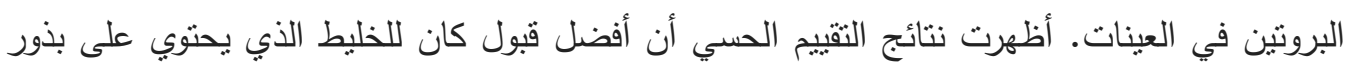

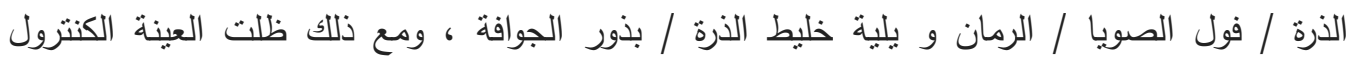

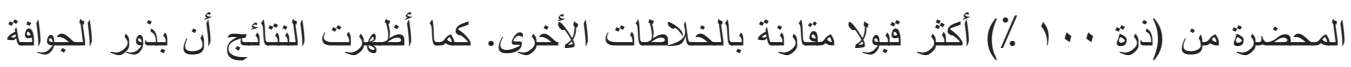

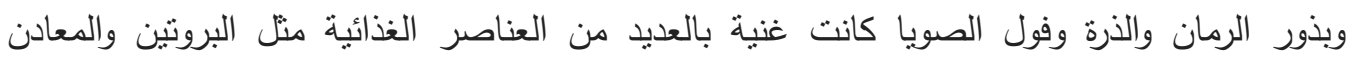
والأحماض الدهنية والألياف والدكونات الدضادة للاكسدة. نتيجة لذلك ، أظهر محتوى البروتين والألياف بلاف

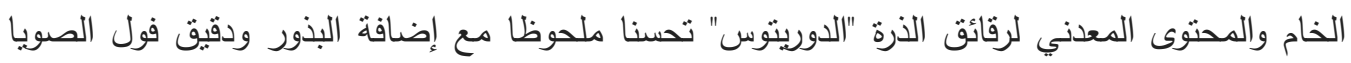

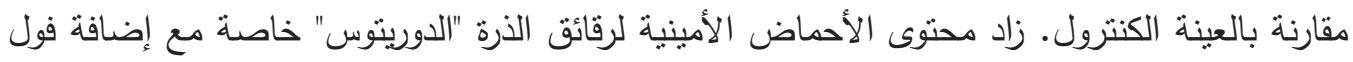

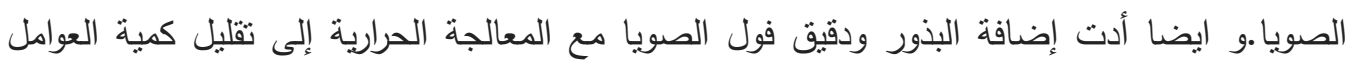

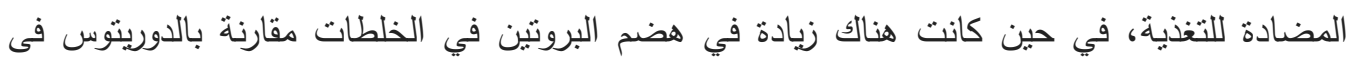

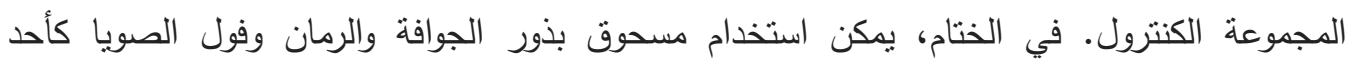

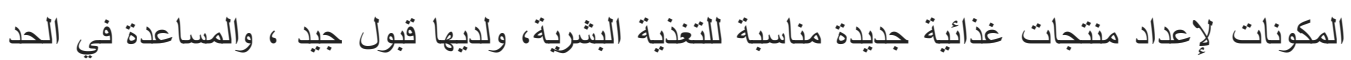
من العديد من الأمراض وتساعد أيضًا في الحفاظ على البيئة نتيجة لاستخدام هذه المخلفات.

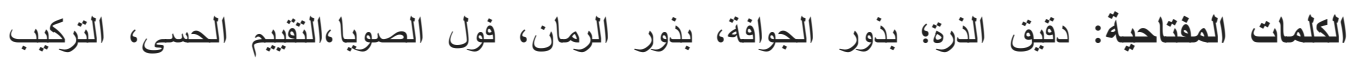

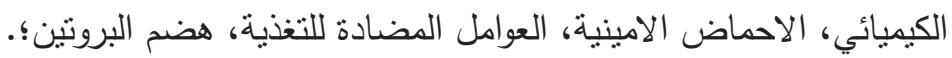

